\title{
Crisis of the Modern Age and the Way Out: An Examination of T. S. Eliot's Four Quartets
}

\author{
Dr. Fatima Falih Ahmed Al-Badrani \\ Assistant Professor, South Carolina University, USA \\ Dr. Abdullah Fawaz Al-Badarneh \\ Assistant Professor, Department of English, \\ Jerash University, Jerash, JORDAN
}

doi: 10.19044/esj.2016.v12n2p225 URL:http://dx.doi.org/10.19044/esj.2016.v12n2p225

\begin{abstract}
The twentieth century was one of change and unrest. What characterises the age is that society, up to a high degree, was hostile to spiritual life. The spiritual values seemed to be neglected or totally abandoned for the material, more matter-of-fact values. This left society in a state of increasing confusion that was substantially realised in the outbreak of World War I. The impact of the war revealed the degeneration of the modern world with the breakdown of religion and moral and spiritual traditions. T. S. Eliot was fully aware of the ills of modern civilisation that surrounded people with a number of faiths established haphazardly to fight against the troubles of modern life. These faiths refer to political and social ideologies, parties, and allegiances. Eliot finds that all modern ideologies are poor and futile substitutions for religious faith. He finds that society should be built not upon power and its corruption, but upon a higher system of values which are mainly spiritual and moral.

This research paper demonstrates how Eliot's Four Quartets affirms the possibility of spiritual regeneration and gives a positive projection of hope. The central theme of the poem is that if the heart of the individual is ever to be at rest, if his/her tormented apprehension about the transience of human life is ever to be calmed, it will be so when he/she accepts the conviction that humans' peace is in God's will.
\end{abstract}

Keywords: Faith, modern age, moral crisis, moral values, religion, spiritual ideals, unbelief

"Ours is a tragic age, but we refuse to take it tragically"

D. H. Lawrence, Lady Chatterley's Lover 


\section{Introduction}

The modern age was marked by the triumph of science, invention, and secularism over theology as the new source of truth. When German philosopher Friedrich Nietzsche famously declared that God is dead, and Wittgenstein proclaimed that humans would do better to pass silence over things they cannot speak about, modernity forced the divine into silence. Few works broke this silence and T.S. Eliot's literary masterpiece Four Quartets was among them.

Modernism was also an era that broke away from the previous, and experimentation dominated the western world. Europe and most of the western world were suffering from the scars of World War I, and the values of industrialisation, social development, and scientific advancement of the Victorian era appeared to falter and cause disillusion and confusion in the western world. Philosophers and writers attempted to find a solution and to propose new perspectives. Eliot witnessed the turmoil of the era and was heavily influenced by modernism.

Four Quartets is structured as a four-poem sequence and around 900 lines long. In sum, it includes a Christian's existential reflections at a time of profound change and crisis. Flowing from personal experience, all four poems are titled after places Eliot considered significant in his past and present life: Burnt Norton for a mansion in Gloucestershire where he spent the summer in 1934; East Coker for a village in the $17^{\text {th }}$ century when Eliot's family moved to America; The Dry Salvages for a rock formation off Cape Ann near Gloucester, Massachusetts; and Little Gidding for a village in Huntingdonshire where Anglican monk Nicholas Ferrar founded a religious community.

Aside from their deeply personal significance, the four poems are structured in an interrelated manner, then, they are unified through various symbolisms and imagery. For instance, the imagery of all four poems is composed of elements of fire, air, earth, and water to represent the cosmos and human existence. Throughout all four poems, Eliot's objective is clear: to evoke as completely as possible the natural, historical, and cosmic context of an individual's journey towards God. This objective is in response to his diagnosis of the defects and chaos of the modern era.

\section{Loss of Feeling, Loss of Meaning: The Crisis of the Modern Age}

Eliot laid out his diagnosis of the modern age in Four Quartets as one springing from a confused theology. Preceded to Eliot's generation, there was a triumph of the deterministic sciences which had nearly successfully decimated the authority of scripture and theology, which had previously directed the lives of generations past. In place of the Genesis account of creation, modern astronomy had come up with a deterministic theory of the 
universe. Furthermore, the creationist doctrine had been supplanted by biology when Darwin and Huxley reduced the privilege status of man as God's special creation to mere products of evolution. To understand social problems, Comte developed a historical theory that can explain society's development from a positivist stance, thereby abandoning the theological and metaphysical explanations on how societies are formed. Marx formulated an economic theory, founded on determinism which diagnosed exploitation to private property and wealth accumulation. Furthermore, it is held responsible for the inevitability of class conflict and the dictatorship of the proletariat. Meanwhile, Freud proposed a theory of the unconscious that subverted assertions of theology on the intricacies of mental life. In all aspects of knowledge, theology had, in one way or another, struggled with rationality and determinism. Even ethics and social values, grounded previously in revelation, became challenged, but some scholars attempted to salvage the importance of sacred writing to cure what has been largely held as an era of extreme unbelief brought about by modernity.

A. N. Wilson (1999) sketched the historical origins of the so-called rise of unbelief, particularly on Christianity, beginning the $18^{\text {th }}$ century until the early $20^{\text {th }}$ century when a series of scholarly work began to challenge the notions of the supernatural and the authority of revelation. From the publication of Edward Gibbon's The History of the Decline and Fall of the Roman Empire (1776 - 1788), with its diatribe against Christianity's hypocrisy, and David Hume's Dialogues Concerning Natural Religions (1779) which questioned the supernatural, were prominent works that challenged faith in general during the $19^{\text {th }}$ century. More criticisms against faith were lodged with Feuerbach's The Essence of Christianity (1841) and David Friedrich Strauss's The Life of Jesus, Critically Examined (1835). Discourse that challenged creation and the role of religion were Darwin's theory of evolution and Marx's harangue against religion as "opium of the masses" and Feuerbach's assertion that God was a mere projection of humanity's needs.

On the other hand, C. B. Cox, in his "Introduction" to The Twentieth Century Mind (1972), thinks that the heritage of the nineteenth century is demonstrated to be inadequate for the twentieth-century Western mind. The liberal faith in rational progress - that was powerful in the Victorian period-seems impoverished and could not provide sustenance. Having exhausted the spiritual supplies, the Western mind rushed round looking for replacements in magic, science, or in a life of sensation through drugs, sex, or excitement; while some claimed that despair is the only honest response to the chaotic universe (ix).

Eliot's career was devoted to tracing the disorder plaguing the modern world as the effect of "a wrong attitude towards God" (Eliot, 
Christianity and Culture, 49). Exposing the dangers and defects of this modern attitude toward God was the purpose of his prose and the goal to which he is most notably remembered for. He represents the disorders of modernity through his poetry. The poem sequence, Four Quartets, was his greatest work and the fulfilment of his ambition: to diagnose the illness infecting the modern age and to offer a solution. More importantly, the Quartets aimed to restore clarity to the confused modern reader and evoke feelings of religious belief through art. This work has often been regarded as religious poetry because it teaches how to love in the face of indifference and to feel solidarity at a time of alienation and atomisation. Eliot expounded on his diagnosis of the modern world in the essay, "The Social Function of Poetry":

Much has been said everywhere about the decline of religious belief; not so much notice has been taken of the decline of religious sensibility. The trouble of the modern age is not merely the inability to believe certain things about God and man which our forefathers believed, but the inability to feel towards God and man as they did. A belief in which you no longer believe is something which to some extent you can still understand; but when religious feeling disappears, the words in which men have struggled to express it become meaningless. (On Poetry and Poets, 25)

Eliot's past poetry and prose before the Quartets had been consistently critical of the modern world. The universal theme in his work had been the deficiency of human existence in the modern life and the fear that man would not be reduced to animal existence. In fact, in Murder in the Cathedral, Eliot made a clear case for a Christian life. This was what prompted Eliot to work on the Quartets. In his book, A Philosophical Study of T. S. Eliot's Four Quartets (1999), Martin Warner points out that Four Quartets is a kind of answer to The Waste Land, re-engaging with the concerns and sensibilities of the earlier poem from a more ordered and mature perspective, and that the Quartets are more self-consciously the expression of a general situation than the earlier poem (3). The poem's chief goal was to show how a person living in the modern world can live a truly Christian existence (On Poetry and Poets). Eliot's technique was to highlight drama selected from personal experience in order to establish the faith required to make the unfeeling feel. Four Quartets is Eliot's prescription to the loss of feeling and loss of meaning experienced by a human being in the modern world.

\section{Crisis and Resolution in Four Quartets}

The poem sequence is named after locales in both England and America that mark a certain point in human history and theological 
knowledge. The first instalment, Burnt Norton, is set in a rose garden in an old English mansion where the speaker meditates heavily on the clash of time and eternity, the flux of temporal life, materialism and faith as human experiences, and the real reconciliation of both the practical and divine through the Incarnation.

This poem tells of a man who is entrapped in time, seeking the past (memory) and future (speculation), who looks in the gloom of himself, searching for some means by which he can make his life tolerable. At last, he finds the transcendent moment when his own spirit participates in the ordered pattern and harmony of the "Logos" (D. E. S. Maxwell, 157). Robert Lair, in his book on Eliot (1968), suggests that that "Logos" represents the spiritual and ethical laws that are found in religion, which is the great rational principle of all life, the pattern which gives it permanent meaning(53). Warner indicates that Eliot, as a Christian, also saw Christ as logos made flesh. Warner discovers in Four Quartets Eliot's attempt to explore the relations between the various understandings of men and women, and the common logos itself $(29-30)$.

Yet some people, who are entrapped by worldly existence of modern life, neglect those laws and seek their own selfish ends. There must be a search for pattern in a world that is flowing and changing. David Ward states that human flesh shares the flux and transience of life, but their mind longs for such an enduring pattern as found in religion. The chaos of physical life could be transcended and set in order by the realisation of the existence of certain moments in which the experiences of the flesh are contained and consumed (293). Humans must achieve a release of the soul from the body to attain a spiritual permanence and exultation without the compulsions of material existence:

Yet the enchainment of past and future

Woven in the weakness of the changing body,

Protects mankind from heaven and damnation

Which flesh cannot endure.

Time past and time future

Allow but a little consciousness.

The second poem, East Coker, reflects Eliot's experiences in Somerset village and marks the beginning of the speaker's self-reflection and contemplation on the good and bad of modern world. The poem was written in wartime, and Eliot, clearly, saw it as part of the war effort, with its evocation of a possible end to the civilisation of which it is a part. Here, the speaker talks about conflict in desire for "goods of the world" versus the Good itself.

Eliot also underscores the reality of death and destruction of calamity in East Coker. He begins the poem with the initial phrases "Houses rise and 
fall" (1) and "Houses live and die" (2) as a way of emphasising the inevitability of death and destruction. In this poem, Eliot describes how nature never accommodates to human wishes and life does not cease to become a struggle. There is always some form of public or personal calamity that features human existence (Eliot, Christianity and Culture, 177). Humans come to the difficult reality that "[i]t would always be the same," (LG; 42) because as experience may appear to change in time, it only ever remains the same - because there is always the certainty of death:

O dark dark dark. They all go into the dark,

The vacant interstellar spaces, the vacant into the vacant,

The captains, merchant bankers, eminent men of letters,

The generous patrons of art, the statesmen and the rulers,

Distinguished civil servants, chairmen of many committees,

Industrial lords and petty contractors, all go into the dark

(EC; $101-106)$

This world is destined to extinction, even the great sources of light, the sun and the moon; all are swallowed by the darkness, the universal death. This indicates the spiritual darkness or void in which the modern age lives. The soul must be still to see god in the darkness, the humiliation of spirit will lead to a new radiating light: $(123-28)$. The senses then give themselves to death and to God. Only then can it be reborn in the mysterious "agony / Of death and rebirth" (132 - 33). The darkness will be light again and life will be regenerated. The death of sensual life is at once the birth of the spiritual life. This paradox of death and rebirth will bring joy to the hopeless spirit (Maxwell, 157 - 58).

East Coker proceeds with vivid descriptions of doom and suffering in each stanza with the intention of making the reader painfully aware that tragedy is a fixture in human existence. The end of all existence is absence and death. In the end, the world ends and its glory reduced to death and elemental baseness. Martin Scofield in T. S. Eliot: the Poems states that Eliot takes the reader from the vision of doomed sensual joy represented by dancing villagers, into the deepened reality of spiritual communion with God (226).

The third poem, The Dry Salvages, chronicled the gruels of daily human experience such as labour, endurance, and death. In this poem, Eliot successfully illustrates how suffering and labour is eternal and repetitive with no clear reward in sight. Every day that humans toil, they experience suffering and death as inevitability and in considering nature as possible competitor, they have been forced to exploit nature in an attempt to overcome it. Through science and technology and even superstition, humans have made little gods of their own to defeat the inevitable.

To communicate with Mars, converse with spirits, 
To report the behaviour of the sea monster,

Describe the horoscope, haruspicate or scry,

Observe disease in signatures, evoke

Biography from the wrinkles of the palm

And tragedy from fingers; release omens

By sortilege, or tea leaves, riddle the inevitable

With playing cards, fiddle with pentagrams

$(184-191)$

Dry Salvages is Eliot's warning against the temptation of finding various sorts of religious substitutes in order to find meaning and happiness. This could be either modern technology or the occult because of their promise of immediate relief and gratification. In this poem, Eliot exposes a deep personal conflict with modernity. He denounces faith in the new god materialism - and its various representations that are slowly turning humans into beasts and transforming feelings into just twitching of the nerves. He, also, makes this point in Burnt Norton:

The inner freedom from the practical desire,

The release from action and suffering, release from the inner

And the outer compulsion, yet surrounded

By a grace of sense, a white light still and moving,

(70 - 73)

Dry Salvages shows how a human is caught in the flux of life, tormented by its transience, its annunciations of terror and anguish, its threats of inevitable death. Humans have to learn to look beyond the instant of time to the spiritual reality where faith and love enable them to escape time's oppression. The poem dramatises the message of redemption and its elaboration of its meaning for the modern world which suffers a spiritual death.

In the last poem, Little Gidding, Eliot makes his conclusion on how we can gain power over the inevitable as this poem carries the suggestion of spiritual renewal, indicated in the village chapel that was destroyed in 1647 by the Parliamentary army and rebuilt later (Lair, 62). The poem brings the various themes in the previous three to combine them into a unified whole. The theme becomes the redemption of humans and nations from the fire of hell by the fire of purgation, and from the fire of purgation to salvation. It prescribes redemption through humility, repentance, meditation about eternity, patience, and a life of devotion to God. Eliot's prescription is to go back to the age of innocence and simple eternity:

At the source of the longest river

The voice of the hidden waterfall

And the children in the apple-tree

Not known, because not looked for 
But heard, half-heard, in the stillness

Between two waves of the sea.

Quick now, here, now, always-

A condition of complete simplicity

(Costing not less than everything)

And all shall be well and

All manner of thing shall be well

When the tongues of flame are in-folded

Into the crowned knot of fire

And the fire and the rose are one.

$(247-260)$

Little Gidding concludes the Quartets with the promise that "all shall be well" when humility and self-denial teach humans to restore Paradise "[w]hen the tongues of flame are in-folded / Into the crowned knot of fire / And the fire and the rose are one." F. R. Leavis points out that the poem implies the idea of harmony indicated in the word "Quartets" of the title. If humans are to find moments of harmony, of spiritual order, they must do so through humility and prayer, the annunciation of the soul. Humans are to participate in the making up of history in the spiritual vision of God (111).

\section{The Concept of Time}

Throughout the Four Quartets, Eliot emphasises the role of time and how the element of time is interconnected in all four quartets. The beginning of each quartet deals with time. Eliot begins and ends East Coker with "in my beginning is my end" (1) and "In my end is my beginning" (209), to connect the entire quartet to a linear time plane. His response or resolution to the chaos in the world is the dissipation of time and to focus his attention to the present, such that the self-reflection and understanding are within reach, which is the present. Eliot demonstrated the non-linearity of time in the structure of the four quartets.

Burnt Norton represents the present for Eliot. He has spent significant moments in a country house in Gloucestershire with Emily Hale in the summer of 1934. The setting of East Coker is a village in Somerset, England, which represents his historical past. The ancestors of Eliot were from this village before they migrated to America in 1649. East Coker bridges the gap between the American and English cultures. The last quartet has a significant cultural history. The setting was a village where Charles I hid the night before he was beheaded. By reverting to the historical past, Eliot reiterates the cyclical nature of time. Katie Reece Moss (2008) views this perspective on time as a method of resolution; that "the past and the present must work together in harmony in order to hope for a resolution in the future...to move 
past the external pressures of the world toward an internal consciousness that has transcended those linear constructs" (37).

Through the four quartets, Eliot expresses his horrors and anxiety associated with war during his time as he finds a way to deal with those fears and finds a way to move on and move towards self-progress. Eliot expresses his thoughts in Little Gidding and writes, "Ash on an old man's sleeve / Is all the ash the burnt roses leave" (54 - 55). The roses are burned to ashes, and only the ash remains, which alludes to the say way that the past tends to remain within the present. By reconciling the past with the present through the four quartets, Eliot is able to find a way to share the internal suffering.

Eliot acknowledges the pain and suffering of war, but he hopes to find something more. He writes, "We shall not cease from exploration / And the end of all our exploring / Will be to arrive where we started / And know the place for the first time" $(240-243)$. To succeed in the future, one has to deal with the external chaos of the past. Moss observs that Eliot "manages to come to terms with the external chaos of the era, specifically the wars, and looks to the future for a sense of hope" (40).

\section{Stillness}

Eliot describes stillness as the "still point of the turning world" in the Four Quartets, implying that a moment of stillness amid a chaotic situation is necessary. For Eliot, the "world may continue to turn, but the individual consciousness within that turning world must remain still" (Moss 41). Eliot describes this stillness in the Quartets:

At the still point of the turning world. Neither flesh nor fleshless;

Neither from nor towards; at the still point, there the dance is,

But neither arrest nor movement. And do not call it fixity,

Where past and future are gathered. Neither movement from nor towards

Neither ascent nor decline. Except for the point, the still point,

There would be no dance, and there is only the dance.

I can only say, there we have been: but I cannot say where.

And I cannot say, how long, for that is to place it in time.

(BN; 62 - 69)

This still point offers a way toward hope and renewal by understanding the past, present, and future simultaneously. Throughout the four quartets, Eliot expresses his desire to achieve this stillness to deal with obstacles of the present and avoid the traps that prevent the achievement of stillness he aspires. Eliot aspires to find "The inner freedom from the practical desire, / The release from action and suffering, release from the inner / And the outer compulsion, yet surrounded / By a grace of sense, a white light still and moving," (BN; 70 - 73). Eliot warns against the 
extremes, such as dark and light, which hinders stillness. He points out that still point occurs "[i]n a dim light: neither daylight [. . . .] suggesting permanence / Nor darkness [. . .] Cleansing affection from the temporal [. . .] [but] Only a flicker [. . . T That blows before and after time" (BN; 92 - 105). Escaping from his own darkness, Eliot will search a place in which "the fire and the rose are one" (LG; 260).

\section{Reconciliation}

Throughout the text in Four Quartets, Eliot deals with opposing concepts or paradoxes that seem to create dissonance. Some examples of paradoxes from Little Gidding, II, include "near the ending of interminable night," "one walking, loitering and hurried," "both one and many," "both intimate and unidentifiable" (79, 86, 94, 96), and so on. Reconciliation is achieved when two opposing concepts meet and eventually come to full circle, such as "I was still the same, / Knowing myself yet being someone other -" (99 - 100). These paradoxes regarding the self may represent the life of the poet at some juncture. Eliot understands that these paradoxes may prohibit individual progress, but at the same time, these concepts may increase the opportunity to achieve time. Eliot understands that one must reconcile with the past to enable the individual to progress to another level. In general, the poetry of Eliot "becomes the vehicle through which the present may be confronted in all its chaos, its change, its wartime destruction and post-war shell-shock, while the role of the past is sustained by an intellectual homage" (Malamud, 75). Specifically, Eliot writes in Dry Savages that although the "past has another pattern" (86) and we search for "a means of disowning the past[,]" (89) "the past experience revived in the meaning / Is not the experience of one life only / But of many generations -" (97-99).

To reconcile the past, Eliot points to one's awareness of the natural elements in the environment. Natural elements represent the opposite of patterned elements. Some examples include natural movement, creation of art, non-verbal communication, flora and fauna, bodies of water, and so on, are the objects in the environment that enables the individual to move forward. In the Four Quartets, Eliot uses nature to represent the notion of achieving stillness, and nature inspires the achievement of stillness.

Will the sunflower turn to us, will the clematis

Stray down, bend to us; tendril and spray

Clutch and cling?

Chill

Fingers of yew be curled

Down on us? After the kingfisher's wing

Has answered light to light and is silent, the light is still 
At the still point of the turning world.

$(\mathrm{BN} ; 129-136)$

For Eliot, nature symbolises hope. Lyndall Gordon (1998) confirms that Eliot, when he planned to write the Four Quartets, was searching for "the 'way up"' which is "a life directed by a visionary moment in which the mind perceives a timeless 'reality"' (339). Reading the Four Quartets closely will reveal how Eliot was hopeful about the future. He writes, "There is only the fight to recover what has been lost / And found and lost again and again: and now, under conditions / That seem unpropitious. But perhaps neither gain nor loss. / For us, there is only the trying. The rest is not our business" (EC; 186 - 189).

Like many modernists, Eliot has the same aspiration for resolution. The Four Quartets reflects his desire to maintain his self identity, which he should understand within the context of environment despite the present of chaos (i.e., wars and conflicts the erupted during his time). Although his vision might be an ideal state and he will never achieve complete harmony with the self, he is aware that in order to transcend and move forward, harmony and enlightenment are vital elements. Mary Ann Gillies (1996) observes that, "[i]n effect, the poem is a physical representation of the process of self-discovery" (106). Although Eliot may only be able to progress toward resolution, he may be expected to accomplish selfdiscovery.

\section{Conclusion}

The Four Quartets features a speaker undergoing a series of learning experiences while, at the same time, teaching the soul how to act in an unceasingly temporary existence but, somehow, permanent. This goes on until the speaker reaches the conclusion that what has been lost can be restored to meaning at the least through a restoration of faith.

The Four Quartets is a poem that reaches to the fulfilment of spiritual elevation above the materialism of modern civilisation. Throughout the poem, Eliot seeks assurances that religion can fortify humans against the most seductive of earthly delights and against despair. He constantly stresses the evils against which religion operates. The poem, also, depicts human weaknesses which stand behind spiritual degeneration and lead to a decline in the moral values of the modern age and to the possibility of religious conquest of those weaknesses.

The Four Quartets is Eliot's attempt at restoring the distorted moral and religious values and assuming faith in order to preserve those values from decline. The poem also shows spiritual struggle towards a spiritual realisation to attain peace and harmony with the self and with the outer world. 


\section{References:}

Eliot, T. S. (1991). Four Quartets. Collected Poems: 1909-1962. New York: Harcourt,173 - 210.

Christianity and Culture. (1976). San Diego: Harcourt Brace and Company. On Poetry and Poets. (1957). London: Faber and Faber.

The Complete Poems and Plays 1909-1950. (1980). New York: Harcourt Brace.

The Use of Poetry and the Use of Criticism. (1961). Cambridge: Harvard University Press.

Gillies, M. Henri Bergson and British Modernism. (1996). Montreal: McGill-Queen's UP.

Gordon, L. (1998). Eliot: An Imperfect Life. New York: Norton.

Lair, R. (1968). T. S. Eliot. New York: Barron's Publications, Inc.

Leavis, F. R. (1966). The Common Pursuit. Middlesex: Penguin Books, Ltd.

Malamud, Randy. (1989). The Language of Modernism. Ann Arbor, MI: UMI Research P.

Maxwell, D. E. S. (1961). The Poetry of T. S. Eliot. London: Routledge \& Kegan Paul, Ltd.

Moss, K. (2008). The Power of Timelessness and the Contemporary Influence of Modern Thought,. Web. 20 Nov. 2015

$<$ http://scholarworks.gsu.edu/english_diss>

Ricks, C. (1975). "A Note on 'Little Gidding"'. Essays in Criticism. Vol. 25, 1, $145-53$.

Scofield, M. (1989). T. S. Eliot: the Poems. Cambridge: the University of Cambridge Press.

Ward, D. (1973). T. S. Eliot Between Two Worlds. London: Routledge \& Kegan paul, Ltd.

Warner, M. (1999). A Philosophical Study of T. S. Eliot's Four Quartets. The Edwin Mellen Press.

Wilson, A. (1999). God's Funeral: The Decline of Faith in Western Civilization. New York: Prentice Hall. 